\title{
Development of a Nested Polymerase Chain Reaction Assay for Detection of Colletotrichum acutatum on Symptomless Strawberry Leaves
}

\author{
O. Pérez-Hernández, Department of Plant Pathology, Iowa State University, Ames 50011; M. H. Nam, Nonsan \\ Strawberry Experiment Station, Chungnam ARES, Nonsan, 320-862, Korea; M. L. Gleason, Department of Plant \\ Pathology, Iowa State University; and H. G. Kim, Department of Applied Biology, Chungnam National University, \\ Daejeon 305-764, Korea
}

\begin{abstract}
Pérez-Hernández, O., Nam, M. H., Gleason, M. L., and Kim, H. G. 2008. Development of a nested polymerase chain reaction assay for detection of Colletotrichum acutatum on symptomless strawberry leaves. Plant Dis. 92:1655-1661.

A nested polymerase chain reaction (PCR) assay was developed for detection of Colletotrichum acutatum on symptomless strawberry leaves. In pure culture, the assay detected as little as $1.0 \mathrm{fg}$ of DNA extracted from mycelium and as few as 1.5 conidia $\mathrm{ml}^{-1}$ when conidial suspensions were sonicated. On detached inoculated leaves, three alternative protocols to dislodge the pathogen were assessed: (i) immersion of whole leaves in $0.05 \%$ Tween 20 and manual agitation in plastic bags for $1 \mathrm{~min}$ (A); (ii) immersion in Tween 20, sonication for $30 \mathrm{~min}$, then agitation for $1 \mathrm{~min}$ (SA); and (iii) freezing for $3 \mathrm{~h}$, incubation for 2 days at $27^{\circ} \mathrm{C}$, immersion in Tween 20 , then sonication for $30 \mathrm{~min}$ and agitation for $1 \mathrm{~min}$ (FISA). Each method removed significantly $(P \leq 0.05)$ more conidia from leaves than the nontreated control; however, removal of appressoria did not vary among assays. In composite samples of noninoculated and inoculated $(1.5 \times$ $10^{3}$ conidia $\mathrm{ml}^{-1}$ ) strawberry leaves, the nested PCR assay using the FISA protocol detected $C$. acutatum in as few as 1 infested leaf in 50 noninfested leaves. In a strawberry field, the assay detected the presence of $C$. acutatum in samples of asymptomatic strawberry leaves, showing potential as a powerful tool for reliable diagnosis of the pathogen in the field.
\end{abstract}

Additional keywords: anthracnose, DNA extraction

Anthracnose fruit rot, caused by Colletotrichum acutatum J.H. Simmonds, is a serious disease of strawberry (Fragaria $\times$ ananassa Duch.) worldwide $(7,11,24)$. The disease is characterized by brown, sunken lesions that typically appear as fruit ripen. During warm, rainy weather, anthracnose fruit rot can result in harvest losses of nearly $100 \%$ (11).

A major challenge in managing anthracnose fruit rot is early detection of its causal agent, $C$. acutatum, in the field, because it can survive for extended periods in a symptomless, quiescent stage on and in strawberry plants (16). During the quiescent stage, the fungus can form inactive appressoria or induce latent infections consisting of appressoria with limited development of infective hyphae (31). In this stage, propagules are splash dispersed to different plant organs $(36,37)$. Leandro et al. (15) found that $C$. acutatum could produce secondary conidia on the epidermis of strawberry leaves without inducing

Corresponding author: M. L. Gleason

E-mail: mgleason@iastate.edu

Accepted for publication 27 August 2008.

doi:10.1094/PDIS-92-12-1655

(c) 2008 The American Phytopathological Society symptoms and suggested that infested foliage could constitute a significant source of inoculum for fruit rot.

Identification of sources of inoculum for fruit rot outbreaks is a key step in disease control. Because $C$. acutatum can infest strawberry plants for extended periods without causing symptoms, its presence on or in strawberry plant organs can be missed by visual inspection. Detection of C. acutatum has relied primarily on pathogen isolation on culture media (11). Morphological characterization of the fungus in the laboratory can be time-consuming and may not always provide reliable identification $(6,7,11,16)$. A technique that killed petioles with paraquat, followed by an incubation period (2), posed the disadvantage of relying on a highly toxic pesticide. A freezing-and-incubation technique to detect species of Colletotrichum on strawberry petioles was developed as an alternative to the paraquat technique (19); however, its sensitivity to low concentrations of epiphytic $C$. acutatum has not been established, nor does it discriminate among species of Colletotrichum, requiring further microscopic examination for species identification.

Molecular-based techniques, such as polymerase chain reaction (PCR), may facilitate rapid and sensitive detection of the pathogen in its asymptomatic phase (18).
Specific primers for $C$. acutatum and PCR protocols have been developed to identify the fungus in pure culture $(21,25,26)$. Recently, $C$. acutatum was detected by PCR on asymptomatic organs of artificially and naturally infected strawberry plants (21). However, detection was inconsistent when this PCR protocol (21) was performed on strawberry leaves inoculated with conidial suspensions of $\leq 1.5 \times 10^{6}$ conidia $\mathrm{ml}^{-1}$, which were lower concentrations than those used in the original work (M. H. Nam and O. Pérez-Hernández, unpublished data).

In view of inconsistency in performance of the existing PCR protocol, development of more sensitive detection techniques is of value to the strawberry industry. NestedPCR, which consists of sequential amplification of DNA using two different sets of primers, can increase sensitivity and specificity of PCR in detection of plant pathogens (12). Although the technique has been applied in detection of many plant pathogens $(8,9,13)$, it has not been evaluated for detection of $C$. acutatum. The objective of this study was to develop a PCR-based assay that provides more reliable and sensitive detection of $C$. acutatum in symptomless strawberry leaves than existing assays.

\section{MATERIALS AND METHODS}

Plant material and maintenance. June-bearing strawberry plants (cv. Honeoye) were planted in $15-\mathrm{cm}$-diameter plastic pots containing a 1:2:1 mixture of peat, perlite, and soil, respectively, and maintained in a greenhouse in Ames, IA, at 25 $\pm 5^{\circ} \mathrm{C}$ and a 16 -h photoperiod. Plants were fertilized with a solution of a 21-5-20 fertilizer (400 ppm N; Miracle Gro Excel, The Scotts Company, Marysville, $\mathrm{OH}$ ) as needed.

Pathogen isolate and culture. Cultures of C. acutatum isolate HF-ac-98, obtained from an anthracnose-infected strawberry fruit (15), were grown on potato dextrose agar (PDA; Difco Laboratories, Detroit) plates and incubated at $25^{\circ} \mathrm{C}$ in darkness until conidia developed. To maintain pathogenicity of the isolate, strawberry fruit were regularly inoculated and the fungus was reisolated by scraping conidia from fruit lesions and streaking on PDA plates. To increase inoculum for use in assays, the fungus was grown on modified Mathur's 
medium $(0.1 \%$ yeast extract, $0.1 \%$ bactopeptone, $1 \%$ sucrose, $0.25 \% \mathrm{MgSO}_{4} \cdot 7 \mathrm{H}_{2} \mathrm{O}$, $0.27 \% \mathrm{KH}_{2} \mathrm{PO}_{4}$, and $2 \%$ agar in 1 liter of sterile distilled water [30], amended with $50 \mathrm{mg}$ streptomycin) for 7 to 14 days at $25^{\circ} \mathrm{C}$ in darkness.

In vitro experiments. DNA extraction from conidia and mycelia. Conidial suspensions were prepared in sterile deionized water (SDW) for extraction of genomic DNA. Then, 7- to 14-day-old cultures of $C$. acutatum growing on Mathur's medium were flooded with SDW, the surface of the colony was scraped with a rubber policeman to dislodge conidia, and the resulting suspension was filtered through two layers of cheesecloth into a flask. After concentration was adjusted with SDW to $1.5 \times$ $10^{6}$ conidia $\mathrm{ml}^{-1}$ based on conidia counts under a hemacytometer, the suspension was subjected to serial 10 -fold dilutions to a final concentration of 1.5 conidia $\mathrm{ml}^{-1}$. From each dilution, six 300- $\mu$ l samples were transferred to $1.5-\mathrm{ml}$ Eppendorf tubes. Three samples, as well as a SDW control, were sonicated for $30 \mathrm{~s}$ in an ultrasonic homogenizer (model 4710; ColeParmer Instrument Co., Chicago). A corresponding set of samples was not sonicated. DNA extraction was performed using three alternative methods: hexadecyltrimethylammonium bromide (CTAB; 7,14), $\mathrm{NaOH}$ lysis (29), and the PrepMan Ultra kit (Applied Biosystems, Foster City, CA; 10,28).

For the CTAB method, $300 \mu \mathrm{l}$ of extraction buffer (200 mM Tris-HCl [pH 8.0], $200 \mathrm{mM} \mathrm{NaCl}, 30 \mathrm{mM}$ EDTA, and $0.5 \%$ sodium dodecyl sulfate [SDS]) and $300 \mu \mathrm{l}$ of CTAB buffer $+1 \%$ polyvinylpyrrolidone (PVP) solution were added to sonicated and nonsonicated samples for each conidial concentration. After $500 \mu \mathrm{l}$ of chloroform:isoamylalcohol (24:1) was added, the mixture was centrifuged for 15 min at $13,000 \mathrm{rpm}$ and the supernatant was transferred to a new tube. An equal volume of isopropanol was added to each tube and kept at room temperature (approximately $23^{\circ} \mathrm{C}$ ) for $10 \mathrm{~min}$. After precipitation, samples were centrifuged at $13,000 \mathrm{rpm}$ for 10 min, and the pellet was washed with $70 \%$ ethanol and then dried at room temperature.

For the $\mathrm{NaOH}$ lysis method, $200 \mu \mathrm{l}$ of $0.5 \mathrm{~N} \mathrm{NaOH}$ was added to each sample. The mixture was vortexed for $10 \mathrm{~s}$, then centrifuged at 13,000 rpm for $10 \mathrm{~min}$. The supernatant was removed and immediately diluted with $50 \mu \mathrm{l}$ of $100 \mathrm{mM}$ Tris-EDTA buffer $(\mathrm{pH}$ 8.0). For the PrepMan Ultra method, $30 \mu \mathrm{l}$ of PrepMan Ultra buffer were added to each sample. The mixture was incubated at $56^{\circ} \mathrm{C}$ for $30 \mathrm{~min}$ and then at $100^{\circ} \mathrm{C}$ for $8 \mathrm{~min}$ in a thermocycler (MJResearch PTC-100TM, Watertown, MA), and centrifuged at 13,000 rpm for $2 \mathrm{~min}$. Aliquots (2 $\mathrm{ml}$ each) were used as templates for PCR. Extracted DNA from each sample was suspended in $200 \mu \mathrm{l}$ of SDW and serially diluted, and the concentration of each diluted solution was quantified using a spectrophotometer (model ND1000; NanoDrop Technologies, Inc., Wilmington, DE).

For DNA extraction from mycelium, 1week-old PDA cultures were scraped with a dissecting needle and a small amount of mycelium, collected at the tip of the needle, was transferred to $1.5-\mathrm{ml}$ centrifuge tubes, lyophilized overnight, and ground in 1.5-ml Eppendorf tubes using plastic pestles (Sigma-Aldrich, St. Louis) and diatomaceous earth (Sigma-Aldrich). Genomic DNA was extracted using the CTAB method as described previously, and suspended in $200 \mu \mathrm{l}$ of SDW.

PCR methods, primers, and reactions optimization. Conventional and nested PCR were compared for amplification of the $C$. acutatum-specific fragment. Primer sets CaInt2/ITS4 (25) and TBCA/TB5 (27), which are specific for $C$. acutatum, were used in conventional PCR. In nested PCR, the general fungal primer set internal transcribed spacer (ITS)1-F (33) and ITS4 $(29,33)$ was used in the first PCR round, and specific primers CaInt2 and ITS4 (25) in the second round. Primers were synthesized by the DNA Sequencing and Synthesis Facility of Iowa State University.

PCR reactions were performed in a total volume of $20 \mu \mathrm{l}$, containing $2 \mu \mathrm{l}$ of template DNA, $2 \mu \mathrm{l}$ of each $0.25 \mu \mathrm{M}$ primers, $0.2 \mathrm{mM}$ dNTP, $5 \times$ Green GoTaq reaction buffer, $2.5 \mathrm{mM} \mathrm{MgCl}_{2}, 5 \%$ dimethylsulfoxide (DMSO; Sigma-Aldrich), and 2.5 units of GoTaq Flexi DNA polymerase (Promega Corp., Madison, WI). PCR amplification was based on initial denaturation at $95^{\circ} \mathrm{C}$ for $90 \mathrm{~s}$; followed by $35 \mathrm{cy}-$ cles of denaturation at $95^{\circ} \mathrm{C}$ for $35 \mathrm{~s}$, annealing at $55^{\circ} \mathrm{C}$ for $1 \mathrm{~min}$, and extension at $72^{\circ} \mathrm{C}$ for $1 \mathrm{~min}$; and a final elongation at $72^{\circ} \mathrm{C}$ for 1 min using a MJ Research PTC100TM thermocycler. For nested PCR, $2 \mu \mathrm{l}$ of a 10-fold diluted product of the firstround PCR product was used as template. A negative control was included in all experiments. PCR products were analyzed by electrophoresis on $2 \%$ agarose gel in $0.5 \times$ Tris-borate-EDTA buffer, stained with ethidium bromide $\left(0.5 \mathrm{mg} \operatorname{liter}^{-1}\right)$, and photographed under UV illumination (22).

In vivo experiments. Seven 10 -fold dilutions of a conidial suspension in SDW, ranging from $1.5 \times 10^{6}$ to 1.5 conidia $\mathrm{ml}^{-1}$, were prepared as described previously. From the greenhouse-grown strawberry plants, 112 fully expanded trifoliolate leaves were excised at the petiole base and brought to the laboratory. Leaves in each of eight sets of 14 leaves were arranged adaxial side up on a defined area and sprayed uniformly with the seven conidial concentrations or the SDW control, using an electronic atomizer (Series 571 air compressor; DeVilbiss Inc., Somerset, KY). Within $30 \mathrm{~min}$ after inoculation, one leaf was sampled arbitrarily from each set to quantify the number of conidia sprayed on the leaf surface. Conidia counts were made by excising three disks per leaf with a 1cm-diameter cork borer, immersing the disks in saturated chloral hydrate for 2 days to remove the tissue chlorophyll, mounting each disk on a drop of Hoyer's medium (4), staining with a drop of $0.1 \%$ aniline blue in lactophenol, and then counting conidia under a light microscope at $\times 400$ magnification (15). Ten microscope fields were arbitrarily selected per leaf disk.

The remaining leaves in each set of inoculated leaves and the control were placed separately in crispers (24-by-34-by$6-\mathrm{cm}$ plastic boxes) containing a wire mesh screen and $500 \mathrm{ml}$ of SDW. Leaves were suspended above the water on the wire mesh, and the excised ends of the petioles were inserted through the mesh into the water to minimize desiccation. The boxes were then sealed with tape to maintain approximately $100 \%$ relative humidity and incubated at $25^{\circ} \mathrm{C}$ in darkness for 2 days.

After incubation, leaves were removed from the crispers and air dried at room temperature for $30 \mathrm{~min}$. Again, one leaf was sampled arbitrarily from each set to quantify the number of propagules (conidia and appressoria) of C. acutatum on the leaf surface using the procedure described previously. Subsequently, the remaining 12 leaves from each set were divided into subgroups of 3 leaves each. Three alternative whole-leaf protocols and a control (leaves washed with SDW) were assessed to dislodge the pathogen: (i) a leaf was immersed in $50 \mathrm{ml}$ of $0.05 \%$ polyoxyethylene sorbitan monolaurate (Tween 20) and manually agitated in a sealed plastic bag for $1 \mathrm{~min}$ (A); (ii) a leaf was immersed in $50 \mathrm{ml}$ of $0.05 \%$ Tween 20 , sonicated for $30 \mathrm{~min}$ with an Ultrasonic cleaner (Model B-2200R-1; Branson Cleaning Equipment Company, Shelton, CT), and manually agitated for $1 \mathrm{~min}$ (SA); or (iii) a leaf was frozen for $3 \mathrm{~h}$ at $-20^{\circ} \mathrm{C}$, incubated in a plastic bag with a wet paper towel for 2 days at $27^{\circ} \mathrm{C}$ in darkness, immersed in $50 \mathrm{ml}$ of $0.05 \%$ Tween 20, sonicated for $30 \mathrm{~min}$, and then manually agitated for $1 \mathrm{~min}$ (FISA). Three single-leaf replications were used for each method and each inoculum concentration. After the final step of each assay, $50 \mathrm{ml}$ of the extraction solution was collected in 50$\mathrm{ml}$ plastic centrifuge tubes. Each solution was centrifuged for $10 \mathrm{~min}$ at $4,000 \mathrm{rpm}$, the supernatant was discarded, and the pellet was then resuspended in $1.5 \mathrm{ml}$ of SDW and transferred to 1.5-ml Eppendorf tubes. These samples were centrifuged for $15 \mathrm{~min}$ at $13,000 \mathrm{rpm}$. The pellet was used as a template for total DNA extraction using the three methods described previously, and then DNA was suspended in 300 $\mu \mathrm{l}$ of SDW. Samples were heated for 10 min at $65^{\circ} \mathrm{C}$ to ensure complete suspension. Both conventional and nested PCR 
were performed as described previously, except that, for conventional PCR, only the primer set $C a$ Int2/ITS4 was used. Results of both conventional and nested PCR were compared with those of a freezing technique (19) that was carried out as a control.

After each dislodging protocol, conidia and appressoria of $C$. acutatum remaining on the leaf surface were again counted. Three leaf disks per leaf were each excised, immersed in saturated chloral hydrate, mounted on a drop of Hoyer's medium (4), stained with a drop of $0.1 \%$ aniline blue in lactophenol, and observed under a light microscope at $\times 400$ magnification. The total number of conidia and appressoria were counted in each of 10 microscope fields per leaf disk (15). Data were expressed per square millimeter of leaf area by dividing the total number of conidia or appressoria on each leaf disk by the area of microscope fields observed per disk. Propagule counts on the excised leaf disks were analyzed using single-contrast $t$ tests $(P \leq 0.05)$ to compare the effectiveness of the whole-leaf protocols in dislodging conidia and appressoria. The response variable was the number of conidia, appressoria, or both removed by each dislodging treatment, which was calculated by subtracting the number of propagules that remained on the leaf surface after each dislodging treatment from the number of propagules that were present on the leaf surface before each treatment. Analysis was done using SAS (SAS Institute, Inc., Cary, NC).

Detection threshold in composite leaf samples. To gauge the ability of the assay to detect $C$. acutatum in bulk samples of leaves, 21 fully expanded strawberry leaves from greenhouse-grown plants were collected, inoculated with $1.5 \times 10^{3}$ conidia $\mathrm{ml}^{-1}$, and incubated in crispers for 2 days as previously described. Upon completion of the incubation period, approximately 500 fully expanded strawberry leaves were also collected from the green- house-grown plants and brought to the laboratory. The inoculated leaves were removed from the crispers and air dried at room temperature for about $30 \mathrm{~min}$. Then, each inoculated leaf was combined with 1 , $10,20,30,40$, or 50 noninoculated leaves in a plastic bag and subsequently immersed in $50,100,200,300,400$ or 500 $\mathrm{ml}$, respectively, of SDW containing $0.05 \%$ Tween 20 . Each combination was replicated three times. The samples were then sonicated for $30 \mathrm{~min}$ with an ultrasonic cleaner (model B-2200R-1; Branson Cleaning Equipment Company) and manually agitated for $1 \mathrm{~min}$ (SA assay). After 50 $\mathrm{ml}$ of solution from each sample were collected in 50-ml plastic tubes and centrifuged for $10 \mathrm{~min}$ at $4,000 \mathrm{rpm}, 1.5 \mathrm{ml}$ of the bottom solution, including the pellet, was collected in a 1.5-ml Eppendorf tube. In turn, these samples were also centrifuged for $15 \mathrm{~min}$ at $13,000 \mathrm{rpm}$ and the pellet was resuspended in SDW for use as template for DNA extraction using the CTAB method. For the CTAB method, 300 $\mu l$ of extraction buffer $(200 \mathrm{mM}$ Tris- $\mathrm{HCl}$ [pH 8.0], $200 \mathrm{mM} \mathrm{NaCl}, 30 \mathrm{mM}$ EDTA, and $0.5 \%$ SDS) and $300 \mu$ of CTAB buffer $+1 \%$ PVP solution were added. After 500 $\mu \mathrm{l}$ of chloroform:isoamylalcohol (24:1) was added, the mixture was centrifuged for $15 \mathrm{~min}$ at $13,000 \mathrm{rpm}$ and the upper aqueous phase was transferred into a new tube. An equal volume of isopropanol was added to each new tube and kept at room temperature for $10 \mathrm{~min}$. After DNA precipitation and centrifugation at 13,000 rpm for $10 \mathrm{~min}$, the pellet was washed with $70 \%$ ethanol and dried at room temperature, and DNA was resuspended in $300 \mu \mathrm{l}$ of distilled water. The samples were heated for $10 \mathrm{~min}$ at $65^{\circ} \mathrm{C}$ to ensure complete suspension. Both conventional and nested PCR were performed as described previously; PCR runs in the in vitro and in vivo experiments were performed at least three times.

Field validation. A strawberry field plot with history of anthracnose fruit rot was selected in the Horticulture Research Farm of Iowa State University, near Gilbert, IA. The field was planted in 2005 with the June-bearing cvs. Honeoye and Delmarvel. Renovation, fertilization, insect and weed control, and winter protection followed recommended practices for the region (36).

On 5 and 20 May 2008, the field was inoculated with $1 \times 10^{6}$ and $1 \times 10^{4}$ conidia $\mathrm{ml}^{-1}$, respectively, of an isolate of $C$. acutatum. Between the second inoculation date and the leaf sampling on 19 June, the weather station in the Horticulture Farm recorded 17 rain events ranging from 0.163 to $83 \mathrm{~cm}^{3}$. Anthracnose fruit rot symptoms were common and a severe epidemic of anthracnose fruit rot was underway for about 1 week before leaf sampling was done. All leaves remained asymptomatic throughout the period.

For sampling of leaves, 4.5-m-long sections of matted row were subdivided into 10 quadrats. In each section, samples of 10,30 , and 50 leaves were collected arbitrarily by excising leaves at the base of the petiole. Each sample was replicated 10 times and included lower, middle, and upper leaves. Samples of strawberry leaves from a commercial farm with no history of anthracnose fruit rot, located about $40 \mathrm{~km}$ from the Horticulture Research Farm, were used as controls.

Each leaf sample was assayed by the FISA method as previously described. Genomic DNA was extracted using the CTAB protocol. Nested PCR was performed as described previously; a DNA sample extracted from $C$. acutatum mycelium was used as a positive control.

\section{RESULTS}

In vitro experiments. Conventional PCR using the TBCA/TB5 primers and CaInt2/ITS4 primers provided a detection threshold of $1.0 \mathrm{ng}$ to $10 \mathrm{fg}$ of genomic DNA isolated from mycelium of $C$. $a c u$ tatum. Nested PCR increased detection sensitivity at least 10-fold, to $1.0 \mathrm{fg}$ (Fig. 1).

\section{Conventional PCR}

TBCA/TB5

CaInt2/ITS4

Nested PCR

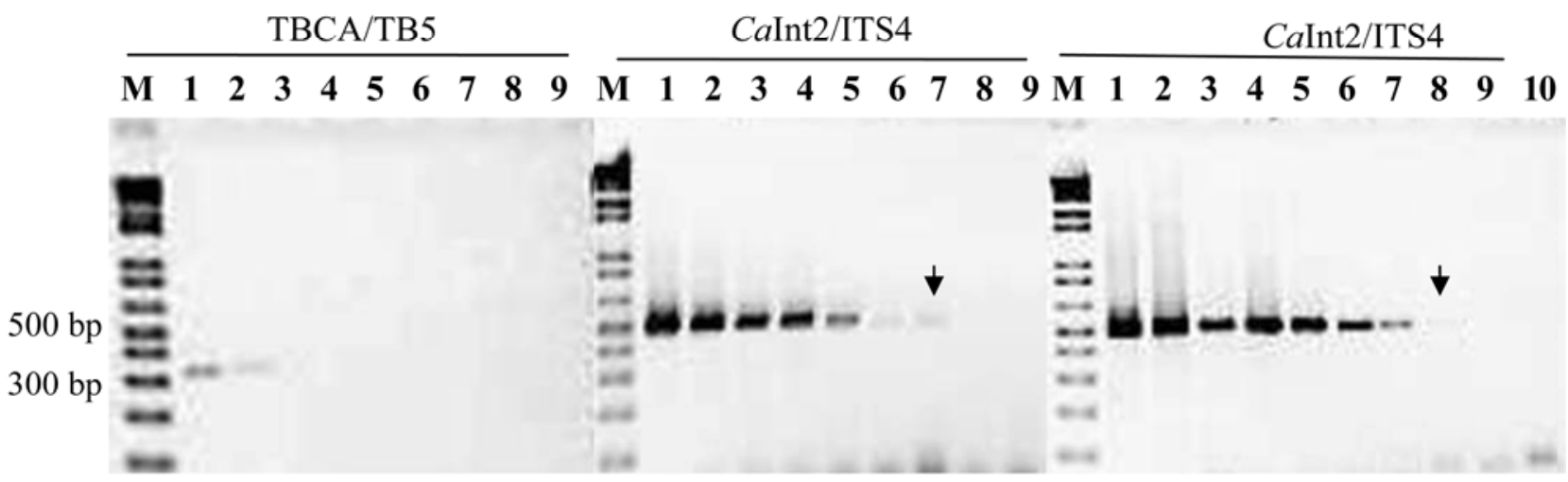

Fig. 1. Polymerase chain reaction (PCR) sensitivity in detecting Colletotrichum acutatum using DNA extracted from mycelium by the hexadecyltrimethylammonium bromide method. Conventional PCR used either primer set TBCA/TB5 or primer set CaIntz/ITS4; nested PCR used primer set ITS1-F/ITS4 in the first round and CaIntz/ITS4 in the second round. Lane M, 100-bp DNA ladder; lane 1, $10 \mathrm{ng}$; lane 2, $1 \mathrm{ng}$; lane 3, 100 pg; lane 4, 10 pg; lane 5, 1 pg; lane 6, $100 \mathrm{fg}$; lane 7, $10 \mathrm{fg}$; lane 8, $1 \mathrm{fg}$; lane 9, $0.1 \mathrm{fg}$; and lane 10, negative control. 
Conventional PCR with TBCA/TB5 primers failed to amplify $C$. acutatum products from conidial suspensions whereas, with the CaInt2 and ITS4 primers, both conven- tional and nested PCR gave amplification products from suspensions of $10^{6}$ and $10^{5}$ conidia $\mathrm{ml}^{-1}$, respectively (M. H. Nam and O. Pérez-Hernández, unpublished data).
Table 1. Detection limit of Colletotrichum acutatum by nested polymerase chain reaction in sonicated and nonsonicated conidial suspensions subjected to three different DNA extraction methods

\begin{tabular}{lccc}
\hline Method & Sonication & Required time $(\mathbf{m i n})$ & Detection limit $^{\left(\text {conidia } \mathbf{~ m}^{-\mathbf{1}} \text { ) }\right.}$ \\
\hline $\mathrm{CTAB}^{\mathrm{a}}$ & No & 80 & $1.5 \times 10^{5}$ \\
& Yes & 82 & $1.5 \times 10^{0}$ \\
$\mathrm{NaOH}$ lysis & No & 30 & $1.5 \times 10^{5}$ \\
& Yes & 32 & $1.5 \times 10^{0}$ \\
PrepMan Ultra kit & No & 68 & $1.5 \times 10^{5}$ \\
& Yes & 70 & $1.5 \times 10^{0}$ \\
\hline
\end{tabular}

a Hexadecyltrimethyl-ammonium bromide.

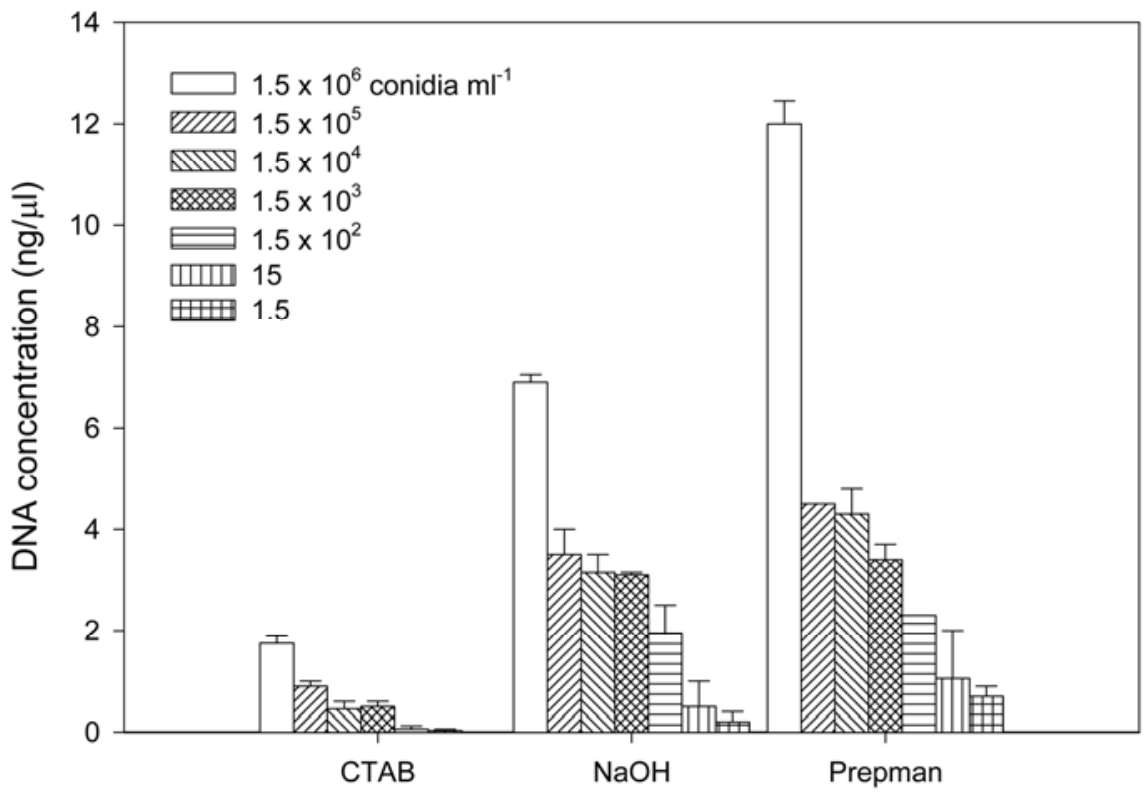

Fig. 2. DNA concentration (ng/ $\mu \mathrm{l})$ from three DNA extraction methods after sonication of conidial suspension. DNA concentration was quantified using a spectrophotometer (Model ND-1000, NanoDrop Technologies, Inc., Wilmington, DE). CTAB = hexadecyltrimethyl-ammonium bromide.

Table 2. Comparison of a freezing technique with a conventional (C) and a nested polymerase chain reaction assay $(\mathrm{N})$ in the detection frequency of Colletotrichum acutatum on inoculated strawberry leaves that were incubated for 2 days and then treated by the agitated (A), sonicated and agitated (SA), and frozen, incubated, sonicated, and agitated (FISA) methods ${ }^{\mathrm{a}}$

\begin{tabular}{|c|c|c|c|c|c|c|c|}
\hline \multirow[b]{3}{*}{ Inoculum $^{e}$} & \multirow[b]{3}{*}{ Freezing $^{f}$} & \multicolumn{6}{|c|}{ Whole leaves } \\
\hline & & \multicolumn{2}{|c|}{$\mathbf{A}^{\mathbf{b}}$} & \multicolumn{2}{|c|}{$\mathbf{S A}^{\mathrm{c}}$} & \multicolumn{2}{|c|}{ FISA $^{d}$} \\
\hline & & $\mathbf{C}$ & $\mathbf{N}$ & $\mathbf{C}$ & $\mathbf{N}$ & $\mathbf{C}$ & $\mathbf{N}$ \\
\hline 0 & $0 / 2$ & $0 / 3$ & $0 / 3$ & $0 / 3$ & $0 / 3$ & $0 / 3$ & $0 / 3$ \\
\hline $1.5 \times 10^{0}$ & $0 / 2$ & $0 / 3$ & $0 / 3$ & $0 / 3$ & $0 / 3$ & $0 / 3$ & $2 / 3$ \\
\hline $1.5 \times 10^{1}$ & $0 / 2$ & $0 / 3$ & $0 / 3$ & $0 / 3$ & $0 / 3$ & $0 / 3$ & $1 / 3$ \\
\hline $1.5 \times 10^{2}$ & $0 / 2$ & $0 / 3$ & $0 / 3$ & $0 / 3$ & $0 / 3$ & $0 / 3$ & $1 / 3$ \\
\hline $1.5 \times 10^{3}$ & $2 / 2$ & $0 / 3$ & $0 / 3$ & $0 / 3$ & $1 / 3$ & $2 / 3$ & $3 / 3$ \\
\hline $1.5 \times 10^{4}$ & $2 / 2$ & $0 / 3$ & $1 / 3$ & $0 / 3$ & $1 / 3$ & $3 / 3$ & $3 / 3$ \\
\hline $1.5 \times 10^{5}$ & $2 / 2$ & $0 / 3$ & $1 / 3$ & $1 / 3$ & $2 / 3$ & $3 / 3$ & $3 / 3$ \\
\hline $1.5 \times 10^{6}$ & $2 / 2$ & $1 / 3$ & $1 / 3$ & $3 / 3$ & $3 / 3$ & $3 / 3$ & $3 / 3$ \\
\hline
\end{tabular}

${ }^{a}$ Numbers separated by the slash symbol indicate the number of samples that tested positive for $C$. acutatum out of the total number of samples (replications) analyzed for each set.

${ }^{\mathrm{b}}$ Whole inoculated leaves were immersed in $50 \mathrm{ml}$ of $0.05 \%$ Tween 20 and agitated in plastic bags.

${ }^{c}$ Whole inoculated leaves were immersed in $50 \mathrm{ml}$ of $0.05 \%$ Tween 20 , sonicated for $30 \mathrm{~min}$ with ultrasonic cleaner, and agitated.

${ }^{\mathrm{d}}$ Whole inoculated leaves were frozen for $3 \mathrm{~h}$ at $-20^{\circ} \mathrm{C}$, incubated in plastic bags with wet paper towel for two days at $27^{\circ} \mathrm{C}$ under illumination, and then immersed in $50 \mathrm{ml}$ of $0.05 \%$ Tween 20 , sonicated, and agitated.

${ }^{\mathrm{e}}$ Inoculum concentration (conidia $\mathrm{ml}^{-1}$ ); $0=$ control (noninoculated leaves sprayed with distilled water).

${ }^{\mathrm{f}}$ Freezing technique: leaves were killed by freezing at $-15^{\circ} \mathrm{C}$ for $3 \mathrm{~h}$, surface disinfested in $0.5 \%$ sodium hypochlorite, and incubated for 5 to 7 days at $25^{\circ} \mathrm{C}$.
The CTAB, NaOH lysis, and PrepMan Ultra kit DNA extraction methods without sonication all detected $10^{5}$ conidia $\mathrm{ml}^{-1}$ in nested PCR (Table 1). When the sonication step was added before DNA extraction, however, nested PCR using each of the three DNA extraction methods detected as few as 1.5 conidia $\mathrm{ml}^{-1}$. Comparison of the three methods of extraction in sonicated and nonsonicated samples showed that the CTAB method required the longest time, whereas the $\mathrm{NaOH}$ lysis method required the least time. Using the PrepMan Ultra kit, DNA concentration from conidia was higher than with other extraction treatments (Fig. 2).

In vivo experiments. Detection of $C$. acutatum varied among whole-leaf assays (Table 2). Conventional PCR detected $C$. acutatum on leaves inoculated with as few as $1.5 \times 10^{6}, 1.5 \times 10^{5}$, and $1.5 \times 10^{3}$ conidia $\mathrm{ml}^{-1}$ that were treated by the A, SA, and FISA methods, respectively. Nested PCR enhanced the detection threshold of C. acutatum compared with conventional PCR and the freezing/incubation technique (Table 2), detecting the pathogen on leaves inoculated with as few as $1.5 \times 10^{3}$ and 1.5 conidia $\mathrm{ml}^{-1}$ and treated with the SA and FISA protocols, respectively. Comparison of the DNA extraction methods showed that amplification of the $C$. acutatum-specific fragment was achieved at $1.5 \times 10^{3}$ conidia $\mathrm{ml}^{-1}$ using the CTAB method whereas, with the $\mathrm{NaOH}$ lysis and PrepMan Ultra methods, amplification was achieved at $1.5 \times 10^{6}$ and $1.5 \times 10^{4}$ conidia $\mathrm{ml}^{-1}$, respectively (Fig. 3).

Dislodging of conidia and appressoria. The number of conidia and appressoria remaining on leaves after each leaf protocol decreased significantly $(P \leq 0.05)$ compared with the nontreated control (Fig. $4 \mathrm{~A}$ ). The fewest conidia $\mathrm{mm}^{-2}$ of leaf area were observed in leaves inoculated with $1.5 \times 10^{6}$ and $1.5 \times 10^{5}$ conidia $\mathrm{ml}^{-1}$ and treated with the FISA protocol but no difference among treatments was evident at lower inoculum concentrations. No conidia or appressoria were observed at $<1.5 \times 10^{2}$ conidia $\mathrm{ml}^{-1}$ after any removal treatment (Fig. 4A). Removal of appressoria did not vary consistently among removal treatments at different inoculum concentrations (Fig. 4B).

Sensitivity of the assay in composite sample experiments. The nested PCR assay consistently detected the pathogen from a single inoculated leaf in samples of 30 leaves or less (Table 3) whereas, in the composite samples of 40 and 50 leaves, the assay detected the pathogen 66.6 and $33.3 \%$ of the time, respectively. Conventional PCR failed to detect the pathogen in any bulk sample of leaves.

Detection of $C$. acutatum in the field. The nested PCR assay detected $C$. $a c u$ tatum in bulk samples of 30 and 50 leaves collected from the infested field; however, in the samples of 10 leaves, no detection 
was evident. The detection frequency among samples was $10 \%$, but the characteristic C. acutatum-specific band (490 bp) was easy to distinguish. All leaf samples collected from the noninfested control site tested negative for C. acutatum.

\section{DISCUSSION}

This study reports development of a sensitive nested PCR assay for detection of $C$. acutatum on asymptomatic strawberry leaves. The assay proved to be reliable in amplifying the C. acutatum-specific DNA fragment $(7,25)$ in reactions using DNA extracted from pure cultures as well as in those with DNA extracted from inoculated plant tissue. Both nonmolecular (19) and PCR-based methods $(7,21,25)$ for detection of $C$. acutatum in strawberry have been published previously. However, the nonmolecular methods usually require 5 to 7 days, and sensitivity of the PCR-based methods for detecting the pathogen on strawberry tissue has not been defined. The nested PCR assay developed in this study can be accomplished in 3 days or less and provides sensitivity 100 - to 1,000 -fold higher than any assay previously reported (21). To our knowledge, our assay is also the first to demonstrate consistency for in vivo detection of $C$. acutatum when performed multiple times. The field validation of the nested PCR method described here shows that this assay can indeed be applied to screen bulk samples of asymptomatic leaves and, potentially, other plant tissues, for detection of $C$. acutatum in strawberry nurseries or production fields. It is possible that the apparently low detection frequency among field samples could be increased with sampling methods guided by greater ecological and epidemiological knowledge of the spatial distribution of C. acutatum in strawberry fields. Bulk sampling is particularly useful when pathogen incidence is low because it assesses a relatively large number of leaves in relatively few assays and, therefore, can enhance detection probability while controlling sampling costs (20). In production fields, it is reasonable to assume that C. acutatum occurs on leaf surfaces prior to appearance of fruit symptoms (36) and that early detection of these infestations using bulk sampling and nested PCR could alert growers to apply

Table 3. Detection of Colletotrichum acutatum by conventional and nested polymerase chain reaction (PCR) in combined samples of inoculated and noninoculated greenhouse-grown strawberry leaves

\begin{tabular}{lccc}
\hline & & \multicolumn{2}{c}{ PCR detection (\%) } \\
\cline { 3 - 4 } Ratio $^{\mathbf{a}}$ & ${\text { Solution }(\mathbf{m l})^{\mathbf{b}}}^{\mathbf{b}}$ & Conventional & Nested \\
\hline $0: 1$ & 50 & 0 & 0 \\
$1: 1$ & 50 & 0 & 100 \\
$1: 10$ & 100 & 0 & 100 \\
$1: 20$ & 200 & 0 & 100 \\
$1: 30$ & 300 & 0 & 100 \\
$1: 40$ & 400 & 0 & 66.6 \\
$1: 50$ & 500 & 0 & 33.3 \\
\hline
\end{tabular}

${ }^{a}$ Ratio of inoculated:noninoculated leaves. Leaves were inoculated with $1.5 \times 10^{3}$ conidia $\mathrm{ml}^{-1}$.

${ }^{\mathrm{b}}$ Amount of solution of sterile deionized water plus $0.05 \%$ Tween 20 in which leaves were immersed and treated.

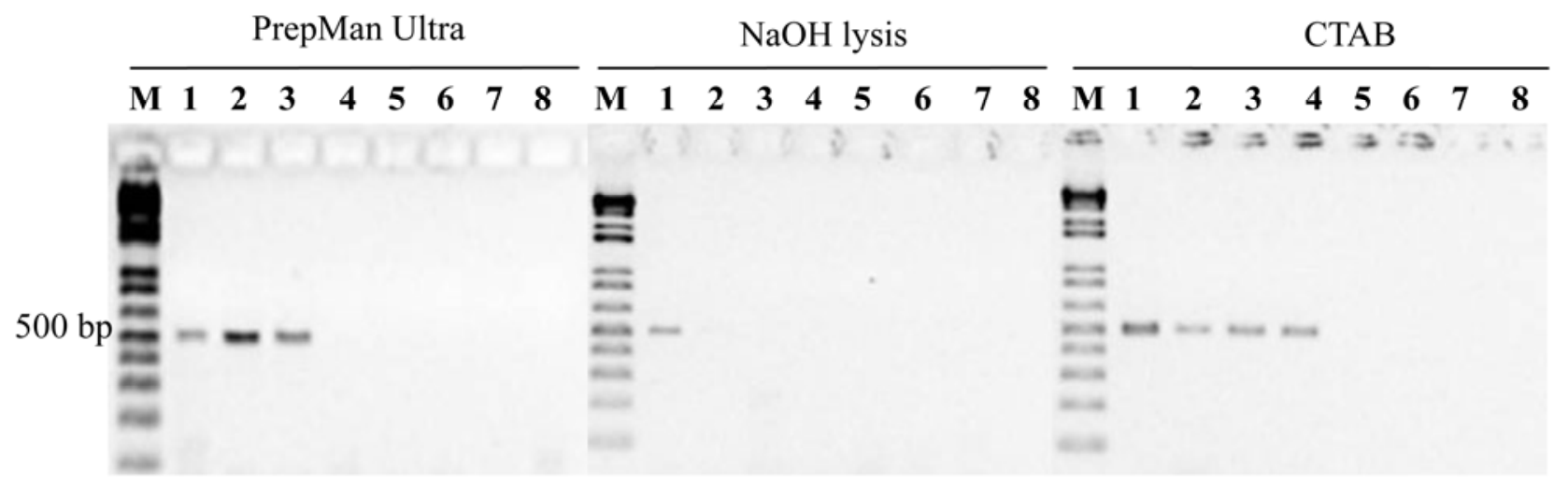

Fig. 3. Amplification of Colletotrichum acutatum-specific fragment by nested polymerase chain reaction from whole-leaf assay solution using three DNA extraction methods. $\mathrm{CTAB}=$ hexadecyltrimethyl-ammonium bromide. Lane $\mathrm{M}, 100$-bp DNA ladder; lane $1,1.5 \times 10^{6}$; lane $2,1.5 \times 10^{5}$; lane $3,1.5 \times 10^{4}$;

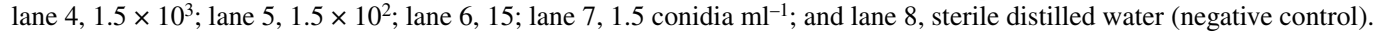
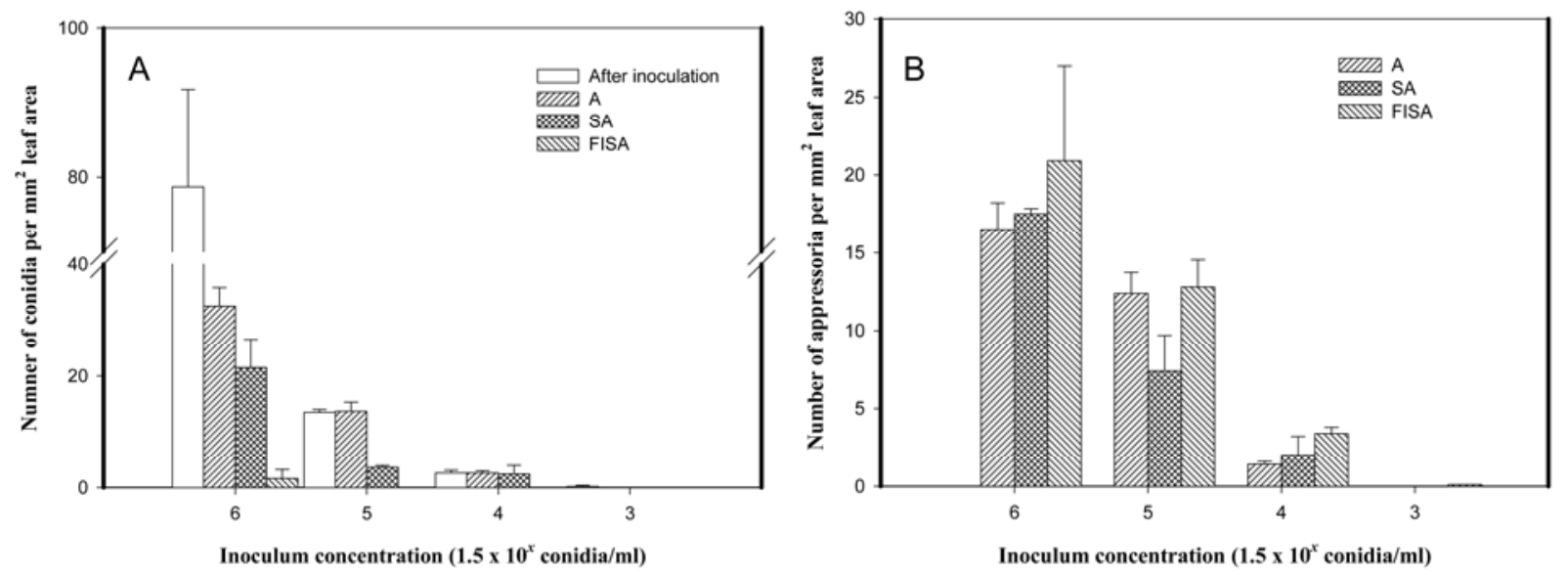

Fig. 4. Number of A, conidia or $\mathbf{B}$, appressoria of Colletotrichum acutatum remaining on the surface of leaves after a 2-day incubation and subsequent treatment with the agitated (A), sonicated and agitated (SA), and frozen, incubated, sonicated, and agitated (FISA) protocols. Error bars represent \pm 1 standard error of the mean. 
fungicide sprays to prevent epidemics. Although other plant organs such as petioles or stolons could be considered for sampling, no information on colonization of them exist and, therefore, there appears to be less rationale to monitor them for presence of the pathogen.

The sensitivity of the nested PCR reported here was confirmed by using conventional PCR as a control. In pure culture, nested PCR increased sensitivity of C. acutatum detection by 100 -fold (25). Increased sensitivity and specificity of nested PCR over conventional PCR was noted in studies of other plant-pathogenic fungi $(3,8,9,12,32)$, where detection was reported to increase from 10 - to 1,000 fold (9) and assays provided detection even in early stages of disease development (8).

A significant enhancement of detection sensitivity was achieved by incorporating a sonication treatment and a CTAB protocol amended with PVP 40. For example, using DNA extracted from conidia with the $\mathrm{NaOH}$ lysis and PrepMan Ultra methods improved the detection limit from $1.5 \times$ $10^{5}$ conidia ml ${ }^{-1}$ in untreated samples to as few as 1.5 conidia $\mathrm{ml}^{-1}$ after sonication. Sonication has been used to increase sensitivity of detection of other phytopathogens on plant surfaces $(1,23,35)$. In the present study, the CTAB method in whole-leaf assays was more efficient than $\mathrm{NaOH}$ lysis and PrepMan Ultra extraction methods. This difference may have been due to elimination of PCR inhibitors in leaf extract solution and higher quality DNA. Wilson (34) reported that polysaccharides and phenolic compounds can inhibit PCR amplification in plant tissue extracts. Treatment with CTAB and PVP can eliminate PCR inhibitors for the detection of phytopathogenic fungi in plant tissue and water samples (17). Jang et al. (14) reported positive detection of Cylindrocarpon destructans using CTAB method with $1 \%$ PVP from ginseng seedling root. In addition, dilution of extracted DNA is an important step for the PCR process (5). In this study, effective amplification of Colletotrichum acutatum was accomplished when the DNA, extracted by CTAB method, was suspended in $300 \mu \mathrm{l}$ of SDW and the first PCR product was diluted 10fold.

The nested PCR assay developed in the current study has potential for application in testing asymptomatic strawberry plant material in diagnostic clinics, and to help growers or consultants determine whether the pathogen is present in given fields. The assay also may be useful as an epidemiological tool for building models that relate epidemic onset to weather conditions favoring risk of anthracnose outbreaks.

\section{ACKNOWLEDGMENTS}

This work was supported by the North Central Region-IPM Competitive Grants Program and the
North American Strawberry Growers Association. Support for the visit by M. H. Nam was provided by the Korean Research Foundation Grant, Korean Government (MOEHRD) (KRF-2006611-F00002). We thank Nourse Farms for donation of the plants; T. C. Harrington, L. F. S. Leandro, and G. R. Nonnecke for comments and suggestions; P. M. Dixon for advice on statistical analysis; and J. Steimel for laboratory advice and assistance.

\section{LITERATURE CITED}

1. Biggerstaff, C. M., Gleason, M. L., and Braun, E. J. 2000. Refinement of a nondestructive tomato seed assay for Clavibacter michiganensis subsp. michiganensis using used fiber. Seed Sci. Technol. 28:261-269.

2. Cook, R. T. 1993. Strawberry black spot caused by Colletotrichum acutatum. Pages 301-304 in: British Crop Protection Council Monograph No. 54: Plant Health and European Single Market. D. Ebbels, ed. Hampshire, UK.

3. Cullen, D. W., Lee, A. K., Toth. I. K., and Duncan, J. M. 2002. Detection of Colletotrichum coccodes from soil and potato tubers by conventional and quantitative real-time PCR. Plant Pathol. 51:281-292.

4. Dhingra, O. D., and Sinclair, J. B. 1985. Basic Plant Pathology Methods. CRC Press, Boca Raton, FL.

5. Doyle, J. J., and Doyle, J. L. 1990. Isolation of plant DNA from fresh tissue. Focus 12:13.

6. Freeman, S., Horowiz, S., and Sharon, A. 2001. Pathogenic and nonpathogenic lifestyles in Colletotrichum acutatum from strawberry and other plants. Phytopathology 91:986-992.

7. Freeman, S., and Katan, T. 1997. Identification of Colletotrichum species responsible for anthracnose and root necrosis of strawberry in Israel. Phytopathology 87:516-521.

8. Glen, M., Smith, A. H., Langrell, S. R. H., and Mohammed, C. L. 2007. Development of nested polymerase chain reaction detection of Mycosphaerella spp. and its application to the study of leaf disease in Eucalyptus plantations. Phytopathology 97:132-144.

9. Grote, D., Olmos, A., Kofoet, A., Tuset, J. J., Bertolini, E., and Cambra, M. 2002. Specific and sensitive detection of Phytophthora nicotianae by simple and nested-PCR. Eur. J. Plant Pathol. 108:197-207.

10. Heller, L. C., Davis, C. R., Peak, K. K., Wingfield, D., Cannons, A. C., Amuso, P. T., and Cattrani, J. 2003. Comparison of methods for DNA isolation from food samples for detection of Shiga toxin-producing Escherichia coli by real-time PCR. Appl. Environ. Microbiol. 69:1844-1846.

11. Howard, C. M., Maas, J. L., Chandler, C. K., and Albregts, E. E. 1992. Anthracnose of strawberry caused by the Colletotrichum complex in Florida. Plant Dis. 76:976-981.

12. Ippolito, A., Schena, L., and Nigro, F. 2002. Detection of Phytophthora nicotianae and $P$. citrophthora in citrus roots and soils by nested PCR. Eur. J. Plant Pathol. 108:855-868.

13. Ito, S., Ushijima, Y., Fujii, Y., Tanaka, S., Kameya-Iwaki, M., Yashiwaru, S., and Kishi, F. 1998. Detection of viable cells of Ralstonia solanacearum in soil using a semi-selective medium and a PCR technique. J. Phytopathol. 146:369-384.

14. Jang, C. S., Lee, J. J., Kim, S. I., Song, J. Y., Yoo, S. J., and Kim, H. G. 2005. Specific detection of root rot pathogen, Cylindrocarpon destructans, using nested PCR from ginseng seedling. Res. Plant Dis. 11:48-55.

15. Leandro, L. F. S., Gleason, M. L., Nutter, F. W., Jr., Wegulo, S. N., and Dixon, P. M. 2001. Germination and sporulation of Colletotrichum acutatum on symptomless strawberry leaves. Phytopathology 91:659-664.

16. Legard, D. E. 2000. Colletotricum disease of strawberry in Florida. Pages 292-299 in: Colle- totrichum: Host Specificity, Pathology, and Host-Pathogen Interaction. D. Prusky, S. Freeman, and M. B. Dickman, eds. American Phytopathological Society Press, St. Paul, MN

17. Ma, Z., and Michailides, T. J. 2007. Approaches for eliminating PCR inhibitors and designing PCR primers for the detection of phytopathogenic fungi. Crop Prot. 26:145-161.

18. McCartney, H. A., Foster, S. J., Fraaije, B. A. and Ward, E. 2003. Molecular diagnostics for fungal plant pathogens. Pest Manage. Sci. 59:129-142.

19. Mertely, J. C., and Legard, D. E. 2004. Detection, isolation, and pathogenicity of Colletotrichum spp. from strawberry petioles. Plant Dis. 88:407-412.

20. Nutter, F. W., Jr., Esker, P. D., and Coelho Netto, R. A. 2006. Disease assessment concepts and the advancements made in improving the accuracy and precision of plant disease data. Eur. J. Plant Pathol. 115:95-103.

21. Parikka, P., and Lemmetty, A. 2004. Tracing latent infection of Colletotrichum acutatum on strawberry by PCR. Eur. J. Plant Pathol. 110:393-398.

22. Sambrook, J., and Russell, D. W. 2001. Molecular Cloning: A Laboratory Manual. Cold Spring Harbor Laboratory Press, Cold Spring Harbor, NY.

23. Schaad, N. W., Berthier-Schaad, Y., and Knorr, D. 2007. A high throughput membrane BIOPCR technique for ultra-sensitive detection of Pseudomonas syringae pv. phaseolicola. Plant Pathol. 56:1-8.

24. Smith, B. J. 1998. Anthracnose fruit rot (black spot). Pages 31-33 in: Compendium of Strawberry Diseases, 2nd ed. J. L. Maas, ed. The American Phytopathological Society, St. Paul, MN.

25. Sreenivasaprasad, S., Sharada, K., Brown, A E., and Mills, P. R. 1996. PCR-based detection of Colletotrichum acutatum on strawberry. Plant Pathol. 45:650-655.

26. Sreenivasaprasad, S., and Talhinhas, P. 2005 Genotypic and phenotypic diversity in Colletotrichum acutatum, a cosmopolitan pathogen causing anthracnose on a wide range of hosts Mol. Plant Pathol. 6:361-378.

27. Talhinhas, P., Sreenivasaprasad, S., NevesMartins, J., and Oliveira, H. 2002. Genetic and molecular characterization of Colletotrichum acutatum causing anthracnose of lupins. Phytopathology 92:986-996.

28. Thorpe, D. J., Harrington, T. C., and Uchida, J. Y. 2005. Pathogenicity, internal transcribed spacer-rDNA variation, and human dispersal of Ceratocystis fimbriata on the family Araceae. Phytopathology 95:316-323.

29. Tooley, P. W., Bunyard, B. A., Carras, M. M., and Hatziloukas, E. 1997. Development of PCR primers from internal transcribed spacer region 2 for detection of Phytophthora species infecting potatoes. Appl. Environ. Microbiol. 63:1467-1475.

30. Tu, J. C. 1985. An improved Mathur's medium for growth, sporulation and germination of spores of Colletotrichum lindemuthianum. Microbios 44:87-93.

31. Verhoeff, K. 1974. Latent infections by fungi. Annu. Rev. Phytopathol. 12:99-110.

32. Wallenhammar, A. C., and Arwidsson, O. 2001. Detection of Plasmodiophora brassicae by PCR in naturally infested soils. Eur. J. Plant Pathol. 107:313-321.

33. White, T. J., Bruns, T., Lee, S., and Tayler, J. 1990. Amplification and direct sequencing of fungal ribosomal RNA genes for phylogenetics. Pages 315-322 in: PCR Protocols: A Guide to Methods and Applications. D. H. Gelfland, M. A. Innis, J. J. Sninsky, and T. J. White, eds. Academic Press, San Diego, CA.

34. Wilson, I. G. 1997. Inhibition and facilitation of nucleic acid amplification. Appl. Environ. Microbiol. 63:3741-3751. 
35. Wilson, M., and Lindow, S. E. 1992. Relationship of total viable and culturable cells in epiphytic populations of Pseudomonas syringae. Appl. Environ. Microbiol. 58:3908-3913.

36. Wise, K. A., Leandro, L. F. S., Wegulo, S. N., and Gleason, M. L. 2003. Survival and dispersal of Colletotrichum acutatum on strawberry foliage under field conditions. Adv. Strawberry Res. 22:14-19.

37. Yang, X., Madden, L. V., Reichard, D. L.,
Wilson, L. L., and Ellis, M. A. 1992. Splash dispersal of Colletotrichum acutatum and Phy tophthora cactorum from strawberry fruit by single drop impactions. Phytopathology 82:332-340. 